\title{
PENGGUNAAN APLIKASI PENDAFTARAN SISWA BARU PADA SEKOLAH MENENGAH ATAS PGRI BALARAJA BERBASIS WEBSITE
}

\author{
Rasyid Tarmizi ${ }^{1}$ \\ Arif Marjuki² \\ Leni Lestari ${ }^{3}$ \\ Dosen STMIK Raharja ${ }^{1,2}$ \\ AMIK Raharja Jurusan Manajemen Informatika ${ }^{3}$ \\ Jl. Jenderal Sudirman No.40 Moderland, Tangerang ${ }^{1,2,3}$ \\ E-mail : rasyid@raharja.info ${ }^{1}$, arif.marjuki@raharja.info ${ }^{2}$, leni.lestari@raharja.info ${ }^{3}$
}

\begin{abstract}
ABSTRAK
Meningkatnya perkembangan teknologi komputer saat ini berkembang pesat yang khususnya terlihat pada ilmu komputer, hal tersebut menjadikan perangkat komputer dilengkapi dengan program aplikasi sehingga dapat digunakan dengan lebih maksimal.

Seiring semakin berkembangnya teknlogi di era globalisasi seperti ini yang dapat mempermudah masyarakat dalam melakukan berbagai aktifitas atau kegiatan pendidikan, perkantoran, perkuliahan, dan lain sebagainya karena telah banyak dirasakan membantu dalam mendapatkan informasi yang cepat, tepat, dan akuran.

Kegiatan pendaftaran siswa baru memiliki hubungan erat dengan kegiatan pendidikan, mulai dari isi form pendaftaran dan juga input pengisian data calon siswa hingga penentuan siswa yang diterima di sekolah, beberapa proses pada penerimaan didik baru ini membutuhkan waktu yang cukup lama.

Tugas Akhir ini menggunakan metode SWOT dan Black Box Testing analisa yang dilakukan maka akan dibuat aplikasi pendaftaran dan penerimaan siswa baru hingga dalam bentuk laporan. Untuk itu, sistem yang akan digunakan akan membantu petugas pendaftaran hingga tahap pembuatan laporan penerimaan siswa baru.
\end{abstract}

Kata Kunci : Pendaftaran Siswa Baru, SMA PGRI, SWOT

\begin{abstract}
Increased development of science and technology is very rapid, especially seen in computer science, this makes computer devices equipped with application programs so that it can be used with the maximum.

Along with the development of teknlogi in the era of globalization like this that can facilitate the community in conducting various activities or educational activities, offices, lectures, and so forth because it has many feel the information fast, precise, and akuran. Admission activities of new students have a close relationship with educational activities, ranging from the content of the registration form and also input filling data prospective students to the limits of students received in school, some of the process on admission of new students takes a long time.

SWOT (Strengths, Weaknesses, Opportunities, Threats), This Final Project uses the SWOT method and the Black Box Testing analysis conducted will be made a new student admissions system that can simplify the process of enrollment of new students in the form of reports. To that end, the system to be used will help the registration officer to stage the preparation of new admissions reports.
\end{abstract}

Keywords : New Student Registration, PGRI Senior High School, SWOT

Vol.5 No.1 - Februari 2019 


\section{PENDAHULUAN}

\section{LATAR BELAKANG}

Meningkatnya perkembangan teknologi komputer saat ini berkembang pesat yang khususnya terlihat pada ilmu komputer, hal tersebut menjadikan perangkat komputer dilengkapi dengan program aplikasi sehingga dapat digunakan dengan lebih maksimal. Seiring semakin berkembangnya teknlogi di era globalisasi seperti ini yang dapat mempermudah masyarakat dalam melakukan berbagai aktifitas atau kegiatan pendidikan, perkantoran, perkuliahan, dan lain sebagainya karena telah banyak dirasakan membantu dalam mendapatkan informasi yang cepat, tepat, dan akuran.

Sekolah Menengah Atas PGRI adalah salah satu lembaga yang bergerak di bidang pendidikan. Pada prinsipnya Sekolah Menengah Atas PGRI selalu berusaha untuk memberikan yang terbaik sesuai kebutuhan, termasuk penerimaan siswa baru. Adanya kebutuhan siswa yang semakin bertambah dan belum terpenuhi oleh sistem penerimaan siswa baru yang ada saat ini, maka diperlukan pengembangan dan penyempurnaan terhadap sistem yang telah ada dengan memperbaiki dari kekurangannya.

Kegiatan penerimaan siswa baru memiliki hubungan erat dengan kegiatan pendidikan yang mana untuk memenuhi kebutuhan akan pendaftaran administrasi siswa sangat dibutuhkan layanan pendaftaran siswa baru yang dapat mempermudah dalam pendataan dan juga mempermudah pendaftaran melakukan permohonan pendaftaran secara cepat.Sekolah Menengah Atas PGRI Balaraja yang berlokasi di jalan Raya Serang Km. 24, 5. Balaraja, Banten adalah sebuah sekolah yang terus meningkatkan pelayanan dalam bidang teknologi.

\section{PERMASALAHAN}

1. Bagaimana sistem pendaftaran siswa baru yang berjalan saat ini pada Sekolah Menengah Atas PGRI Balaraja?

2. Apakah sistem pendaftaran siswa baru yang berjalan saat ini sudah terkontrol dengan baik, dari segi input pendaftaran data siswa, hingga laporan pendaftaran siswa baru?

3. Bagaimana merancang sistem informasi pendaftaran siswa yang dibutuhkan pada Sekolah Menengah Atas PGRI Balaraja?

\section{LANDASAN TEORI}

\section{KONSEP DASAR SISTEM INFORMASI}

Pengertian menurut Krismaji (2015:15) : Sistem informasi adalah cara-cara yang diorganisasi untuk mengumpulkan, memasukkan, dan mengolah serta menyimpan data, dan cara-cara yang diorganisasi untuk menyimpan, mengelola, mengendalikan, dan melaporkan informasi sedemikian rupa sehingga sebuah organisasi dapat mencapai tujuan yang telah ditetapkan.

\section{KONSEP DASAR PENERIMAAN SISWA BARU}

Menurut Saefudin (2013:44), "Penerimaan siswa baru adalah proses dari penerimaan siswa baru yang di mulai dari pendaftaran terlebih dahulu serta memberikan persyaratan valid yang sudah 
ditentukan oleh dinas pendidikan terkait dan sebagai pendataan yang dapat dijadikan informasi yang dibutuhkan sekolah".

\section{DEFINISI BLACK BOX TESTING}

Menurut Kermite dkk dalam Journal of Information Systems (2017:3), "Testing atau pengujian merupakan tahap sebelum mengimplementasikan dan mengoperasikan sistem yang baru, pengujian dilakukan terlebih dahulu untuk mencari error atau bugs pada suatu program”.

Menurut Mustaqbal dalam Jurnal Ilmiah Teknologi Informasi Terapan (2015:31), "Pengujian adalah suatu proses pelaksanaan suatu program dengan tujuan menemukan suatu kesalahan".

Menurut Mingtao Shi dalam Mustaqbal pada Jurnal Ilmiah Teknologi Informasi Terapan (2015:32), "Pengujian atau testing sendiri merupakan elemen kritis dari jaminan kualitas perangkat lunak dan merupakan bagian yang tidak terpisah dari siklus hidup pengembangan software seperti halnya analisis, desain, dan pengkodean".

Berdasarkan pengertian diatas testing merupakan tahap sebelum mengimplementasikan dan mengoperasikan sistem yang baru dengan tujuan menemukan suatu kesalahan pada sistem tersebut.

\section{Definisi Blackbox Testing}

Menurut Kermite dkk dalam Journal of Information Systems (2017:4), "Metode Black Box adalah pengujian kebutuhan dan hanya berfokuskan kepada fungsional dari sebuah perangkat lunak atau program".

Menurut Sari dalam Jurnal Algoritma (2014:2), "Black box testing adalah pengujian yang dilakukan hanya mengamati hasil eksekusi melalui data uji dan memeriksa fungsional dari perangkat lunak.

Menurut Mohd Ehmer Khan dalam Mustaqbal pada Jurnal Ilmiah Teknologi Informasi Terapan (2015:33),"Black-Box Testing merupakan pengujian yang berfokus pada spesifikasi fungsional dari perangkat lunak, tester dapat mendefinisikan kumpulan kondisi input dan melakukan pengetesan pada spesifikasi fungsional program”.

Berdasarkan definisi-definisi tersebut dapat disimpulkan bahwa Black Box Testing adalah metode pengujian yang berfokus pada spesifikasi fungsional dari perangkat lunak.

\section{LITERATURE REVIEW}

1. Penelitian yang dilakukan Muhammad Kahfi: [2013] Penelitian ini membahas tentang penerimaan siswa baru pada SMA Nusa Putra. Penelitian ini dilakukan bertujuan untuk mempermudah proses penerimaan siswa baru pada SMA Nusa.

2. Penelitian yang dilakukan oleh Muhammad Kahfi : [2014] Penelitian ini membahas tentang Analisa Sistem informasi Penerimaan Siswa Baru pada SMA Nusa Putra. Penelitian ini dilakukan untuk mengetahui prosedur dan kendala pada sistem Penerimaan Siswa Baru pada SMA Nusa Putra.

3. Penelitian yang dilakukan oleh Wiranto Herry Utomo dan Shintya Devina [2013] dengan judul : "Xml Web Service Based Integration Modeling Of New Student Admission In Junior High School". Penelitian ini berisi tentang bagaimana merancang dan mengimplementasikan sistem 
berbasis web penerimaan mahasiswa baru. Penelitian ini mengadopsi XML Web layanan teknologi dan metode pengembangan sistem waterfall. Berdasarkan kedua hasil pengujian internal dan eksternal, ditemukan bahwa implementasi perangkat lunak menggunakan metode berkinerja baik.

4. Penelitian yang dilakukan oleh Diki Budi Rahayu, Erwin Gunadhi, dan Partono [2013] dengan judul : "Perancangan Sistem Informasi Pendaftaran Peserta Didik Baru Berbasis Web Studi Kasus Di Sma Negeri 14 Garut”. Penelitian ini berisi tentang perancangan database system dan software interface pendaftaran calon siswa baru berbasis web, sehingga bisa menggantikan sebagian peran dari petugas pendaftaran calon siswa baru. Perancangan aplikasi web ini, akan memberikan banyak kemudahan-kemudahan dalam melakukan kegiatan, terutama yang ada di luar Garut, yang ingin sekali melakukan pendaftaran calon siswa baru dilakukan secara online.

\section{PEMBAHASAN DAN HASIL}

\section{Rancangan Sistem yang diusulkan}

Untuk rancangan sistem usulan ini berdasarkan dari prosedur sistem yang berjalan pada point. 3.2 yang digambarkan pada program Unifed Modelling Language (UML), terdiri dari Use Case Diagram, Activity Diagram dan Sequence Diagram. Tata laksana sistem yang berjalan digambarkan sebagai berikut.

\section{Use Case Diagram yang Diusulkan Use Case Diagram Petugas Sekolah pada Sekolah}

\subsubsection{Menengah Atas PGRI Balaraja :}

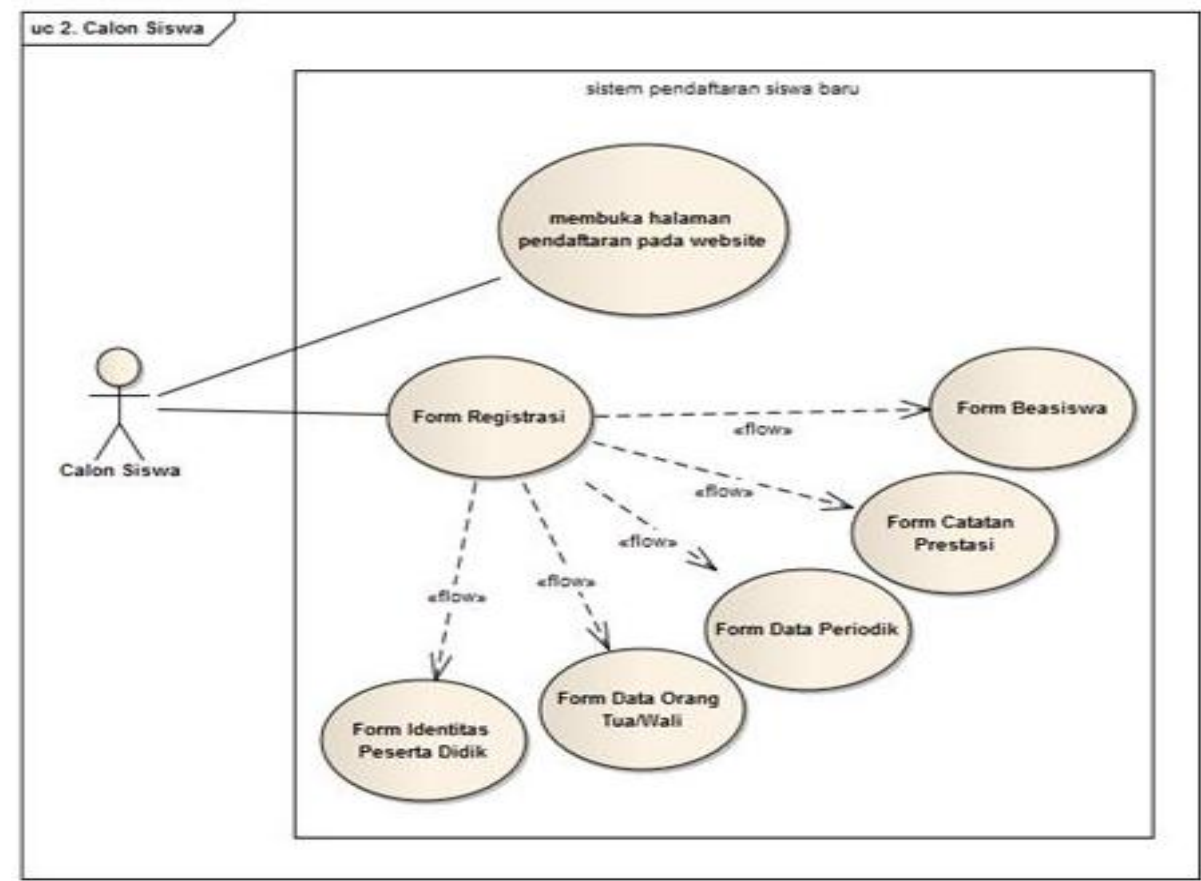

Gambar 1 Use Case Diagram Sistem Usulan Petugas Sekolah 
A. Case : Data registrasi

Actor : Petugas sekolah

Skenario : Petugas melakukan view pada data registrasi hasil dari input form registrasi calon siswa dan dapat melakukan cek status, change status hingga detail.

B. Case : User Management

Actor : Petugas sekolah

Skenario : Setelah petugas login maka memilih menu user management untuk dapat melihat data user dan juga dapat menambahkan data user dengan cara klik tombol tambah user.

C. Case : Setting option

Actor : Petugas Sekolah

Skenario : Setelah petugas melakukan login dapat memilih menu setting option untuk memasukan data sekolah dan logo.

D. Case : Laporan

Actor : Petugas Sekolah

Skenario : Petugas Sekolah akan melakukan rekap data pendaftaran siswa baru hanya dengan cara memilih menu laporan dan generate laporan seseuai waktu yang diinginkan.

\subsubsection{Activity Diagram yang Diusulkan Pendaftaran Siswa Baru Sekolah Menengah Atas PGRI Balaraja}

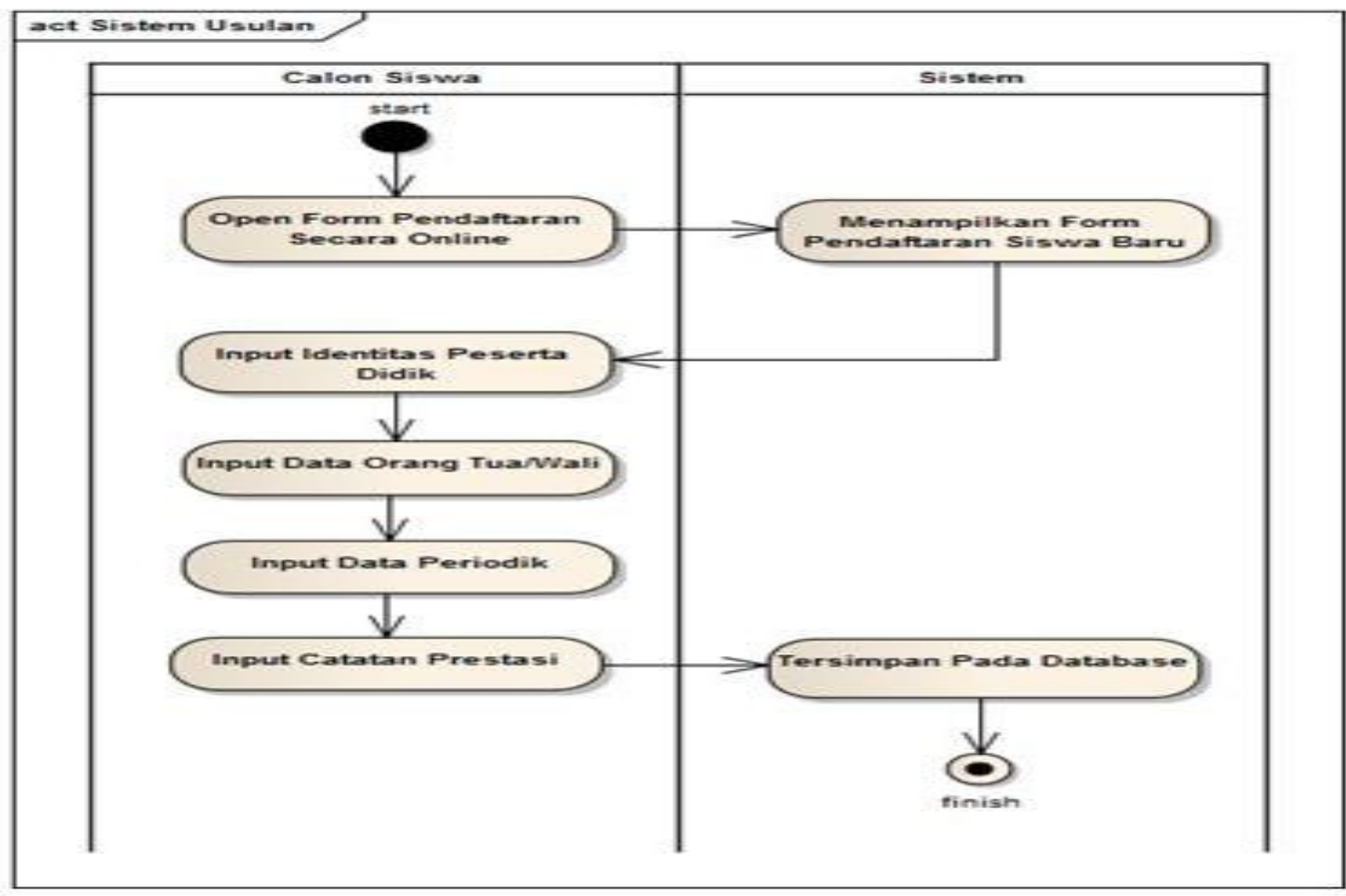

Gambar 2 Activity Diagram Sistem Usulan Pendaftaran Siswa Baru 


\subsubsection{Sequence Diagram yang Diusulkan Pendaftaran Siswa Baru}

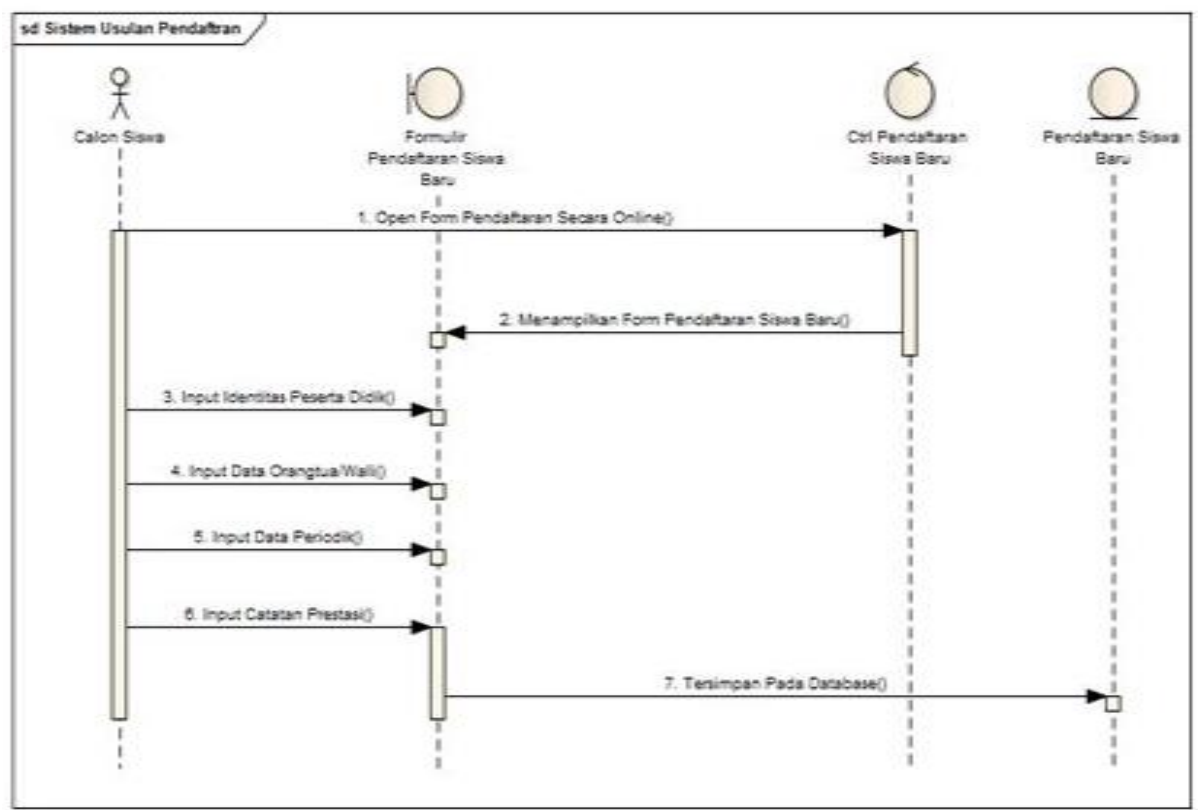

Gambar 3 Sequence Diagram Sistem Usulan Pendaftaran Siswa Baru

\subsubsection{Class Diagram yang Diusulkan}

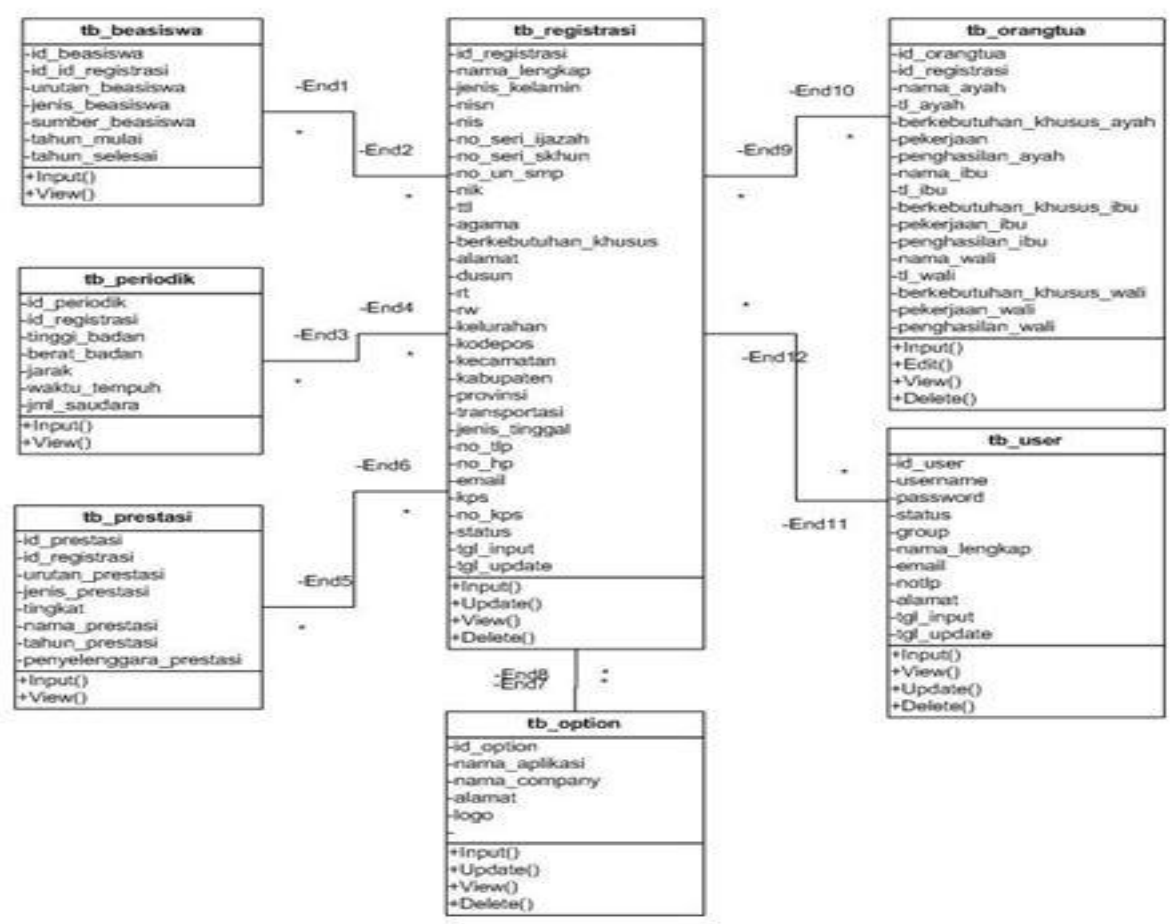

Gambar 4. Class Diagram Pendaftaran Siswa Baru 


\subsection{Tampilan Program}

1. Tampilan Aplikasi Form Indentitas Peserta Didik

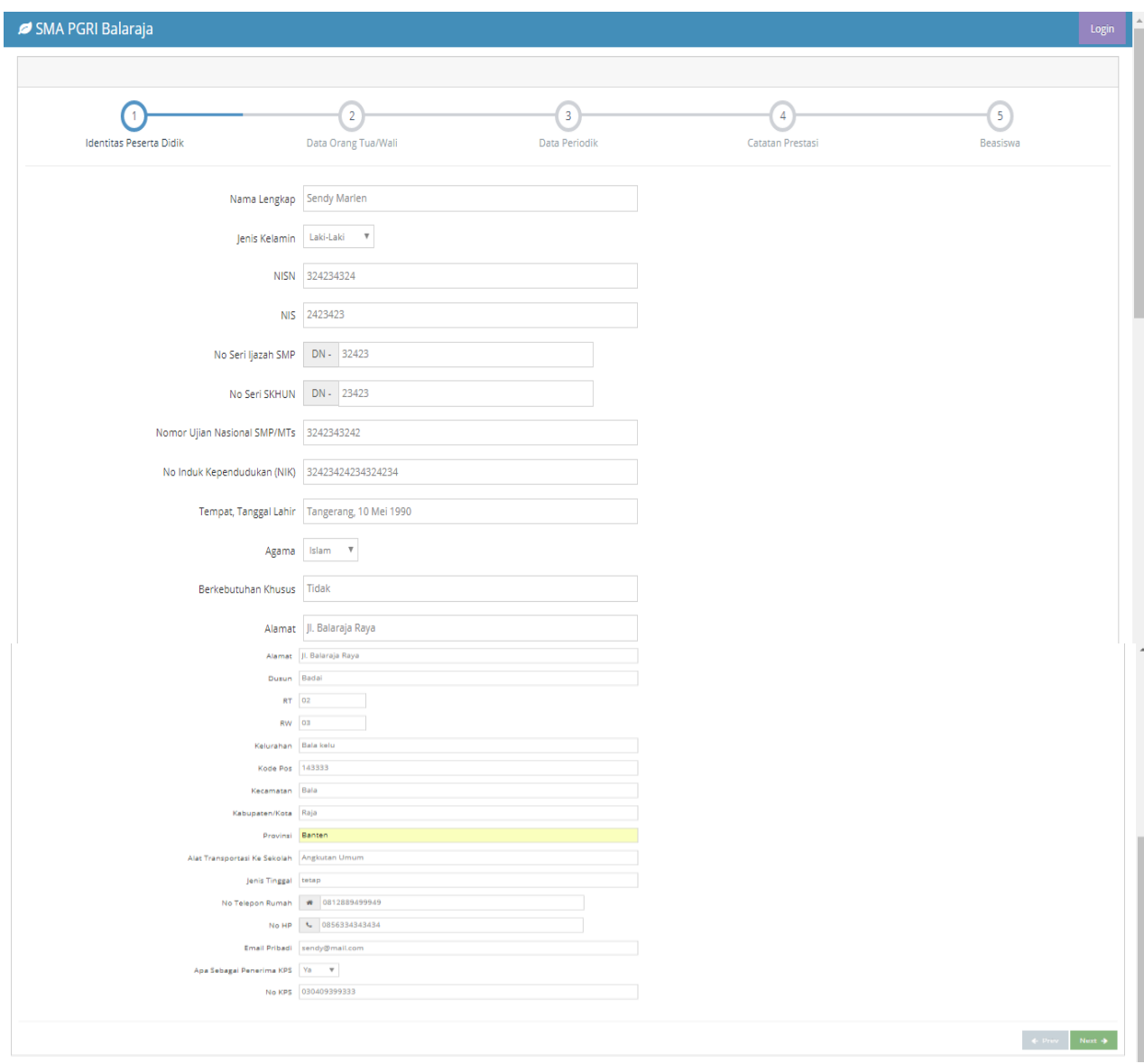

Gambar 5. Tampilan Aplikasi Form Identitas Peserta Didik

2. Tampilan Aplikasi Form Data Orangtua/wali

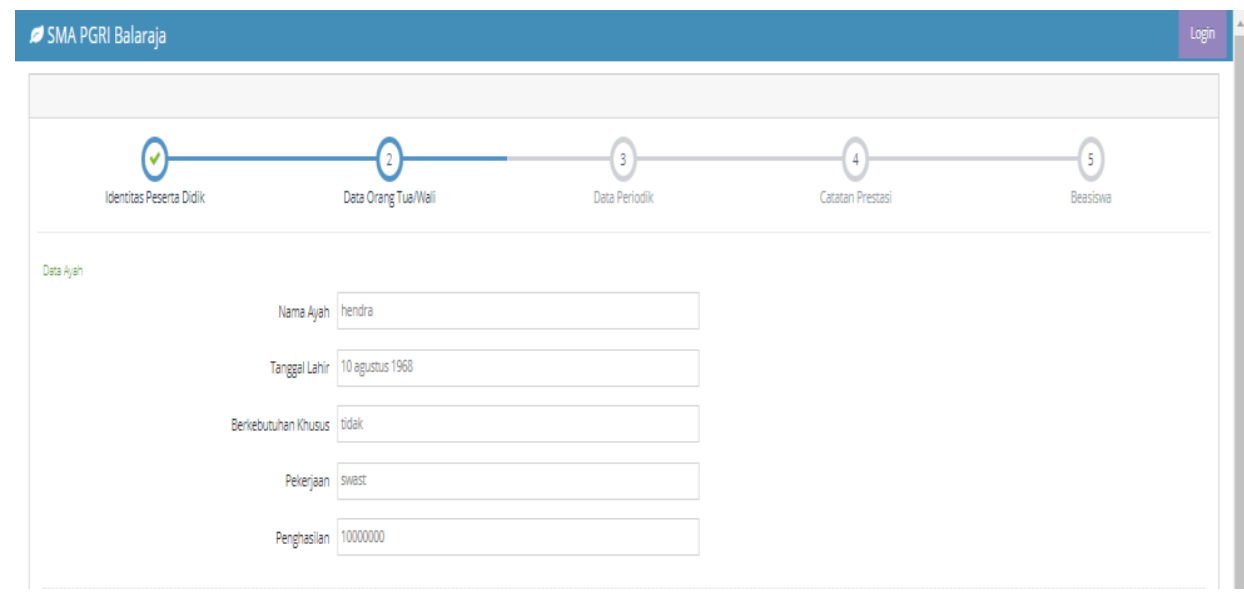

Gambar 6. Tampilan Aplikasi Form Data Orangtua/wali 
3. Tampilan Aplikasi Form Data Periodik

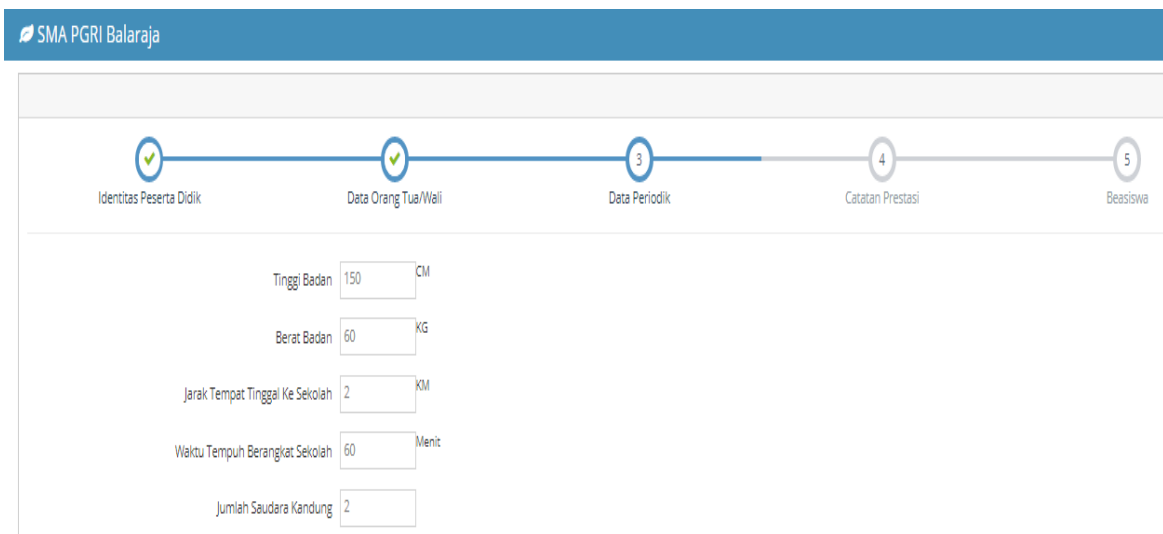

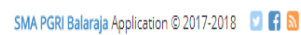

Gambar 7. Tampilan Aplikasi Form Data Periodik

4. Tampilan Aplikasi Catatan Prestasi

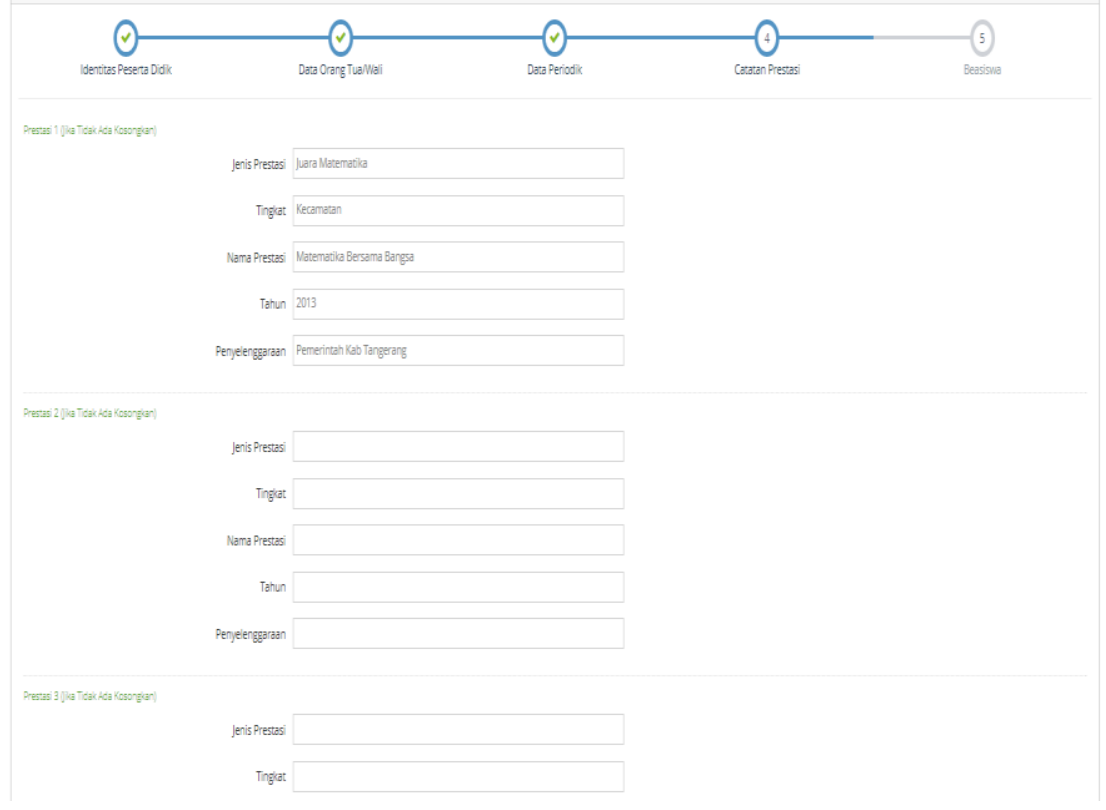

Gambar 8. Tampilan Aplikasi Catatan Prestasi 
5. Tampilan Aplikasi Form Beasiswa

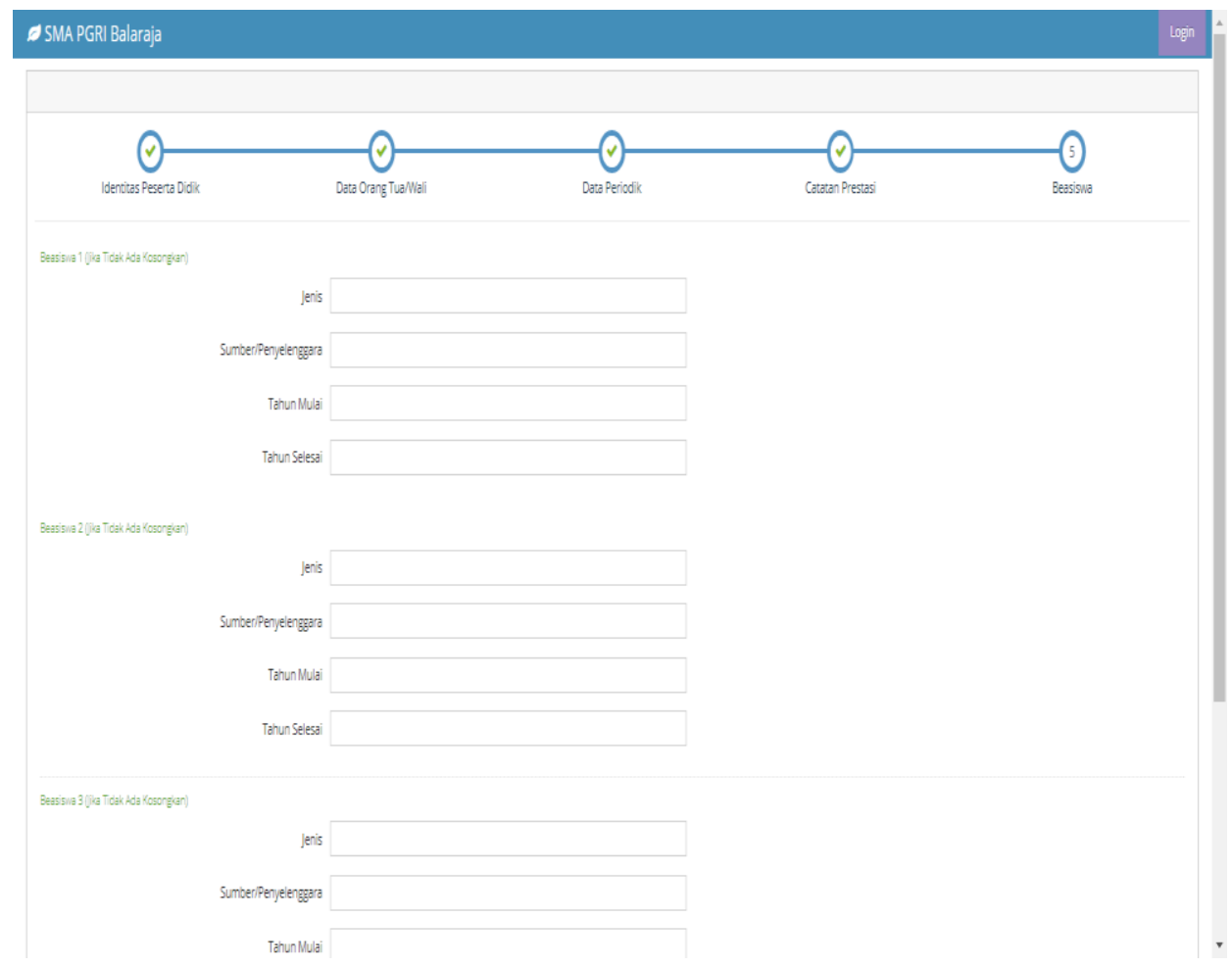

Gambar 9. Tampilan Aplikasi Form Beasiswa

6. Tampilan Aplikasi Proses Berhasil Pendaftaran

Berhasill Laporan Anda Telah di Input ke sistem pelaporan sekolah, ID Registrasi akan dikirimkan melalui e-Mail, ceki INBOX atau Folder SPAM e-Mall anda.

Gambar 10. Tampilan Aplikasi Proses Berhasil Pendaftaran

7. Tampilan Aplikasi Halaman Utama

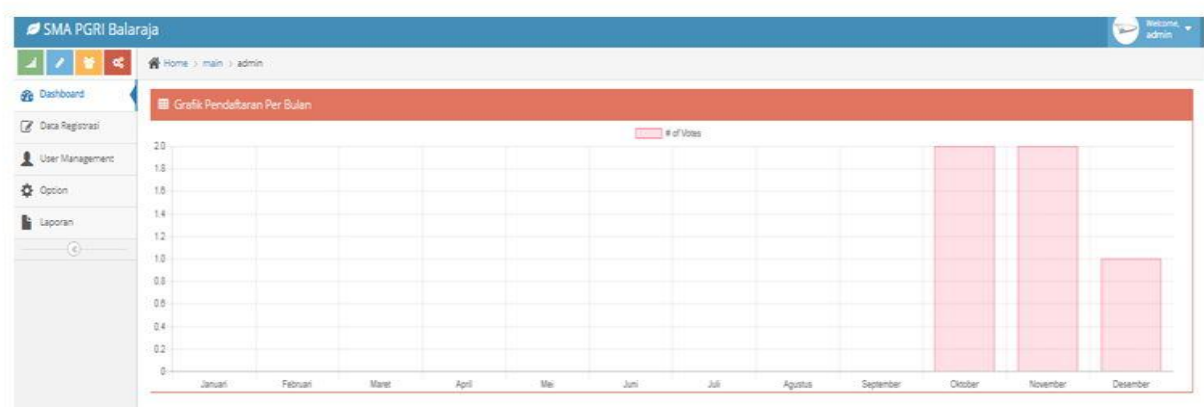

Gambar 11. Tampilan Aplikasi Halaman Utama 
8. Tampilan Aplikasi Data Registrasi

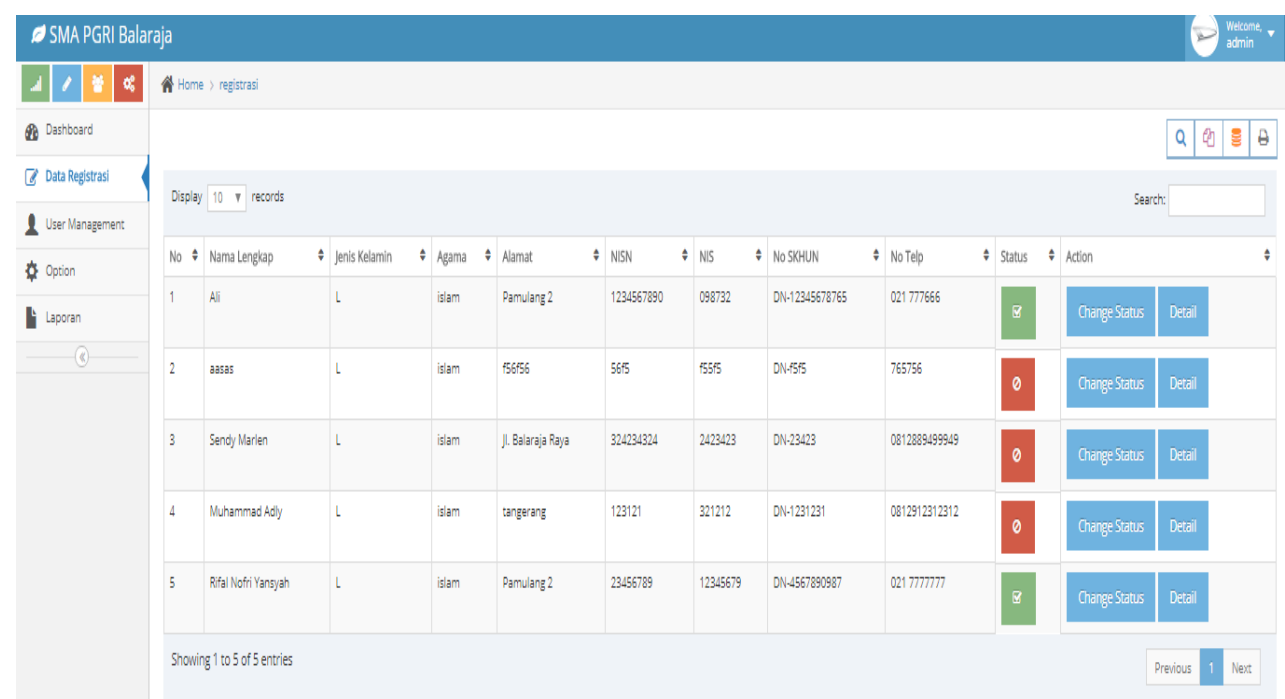

Gambar 12. Tampilan Aplikasi Data Registrasi

9. Tampilan Aplikasi Change Status

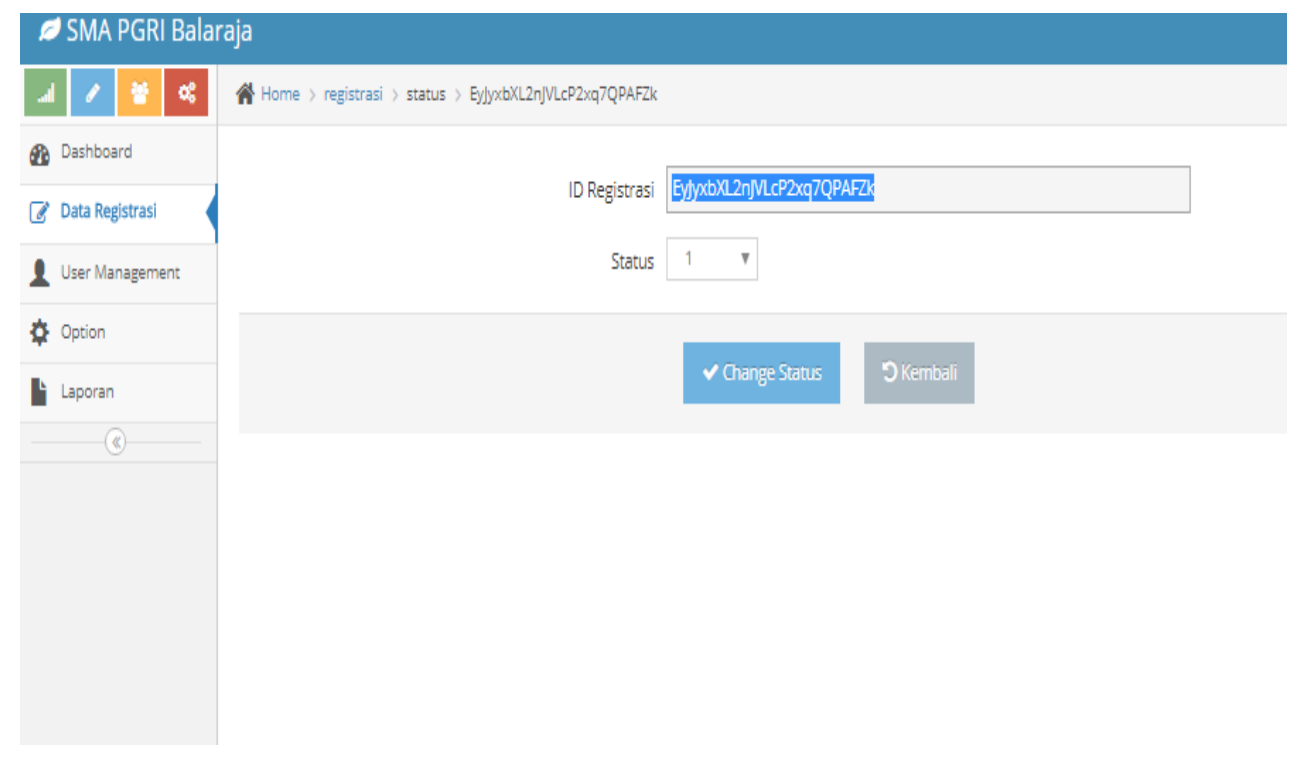

Gambar 13. Tampilan Aplikasi Change Status 
10. Tampilan Aplikasi User Management

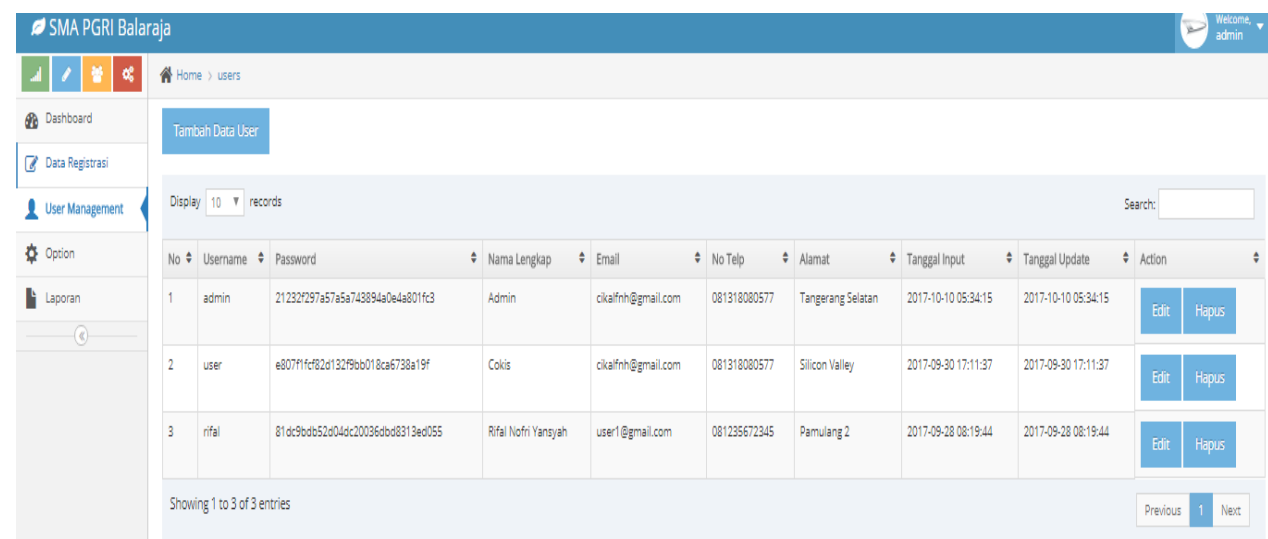

Gambar 14. Tampilan Aplikasi User Management

11. Tampilan Aplikasi Tambah User

\begin{tabular}{l} 
Tambah Data User \\
Username \\
admin \\
Password \\
\hline N.... \\
\hline Nama Lengkap \\
\hline Nama Lengkap \\
Email \\
\hline Email \\
No Telp \\
\hline No Telp \\
\hline Alamat \\
\hline Alamat \\
\hline
\end{tabular}

\section{$x$ Cancel $\checkmark$ Save}

Gambar 15. Tampilan Aplikasi Tambah User 
12. Tampilan Aplikasi Setting Option

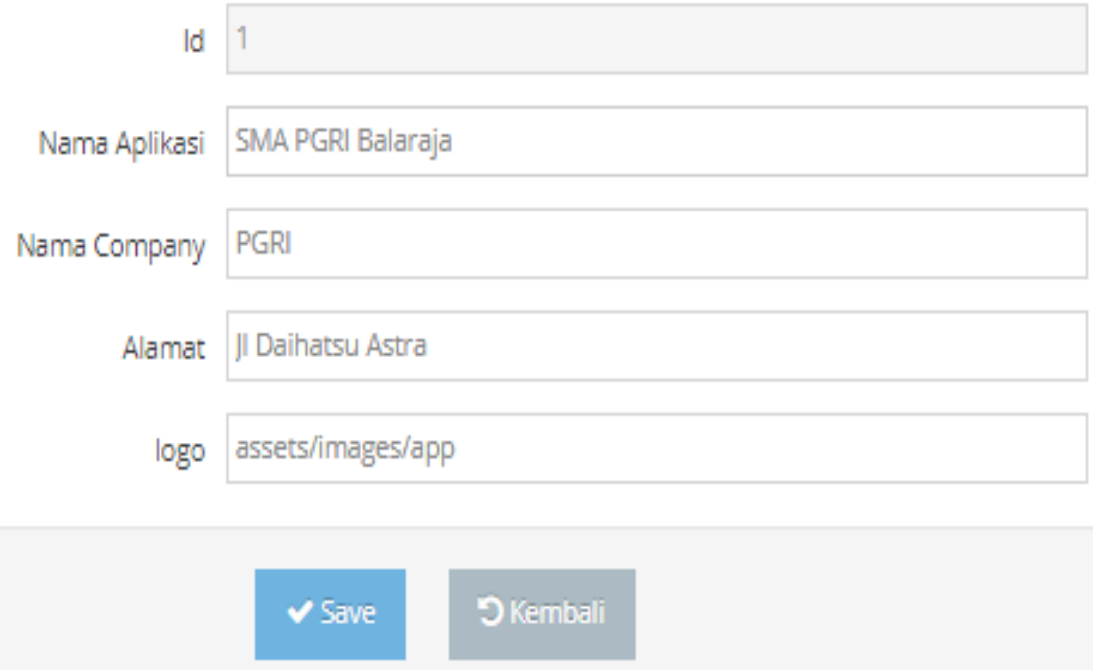

Gambar 16. Tampilan Aplikasi Setting Option

13. Tampilan Aplikasi Setting Option

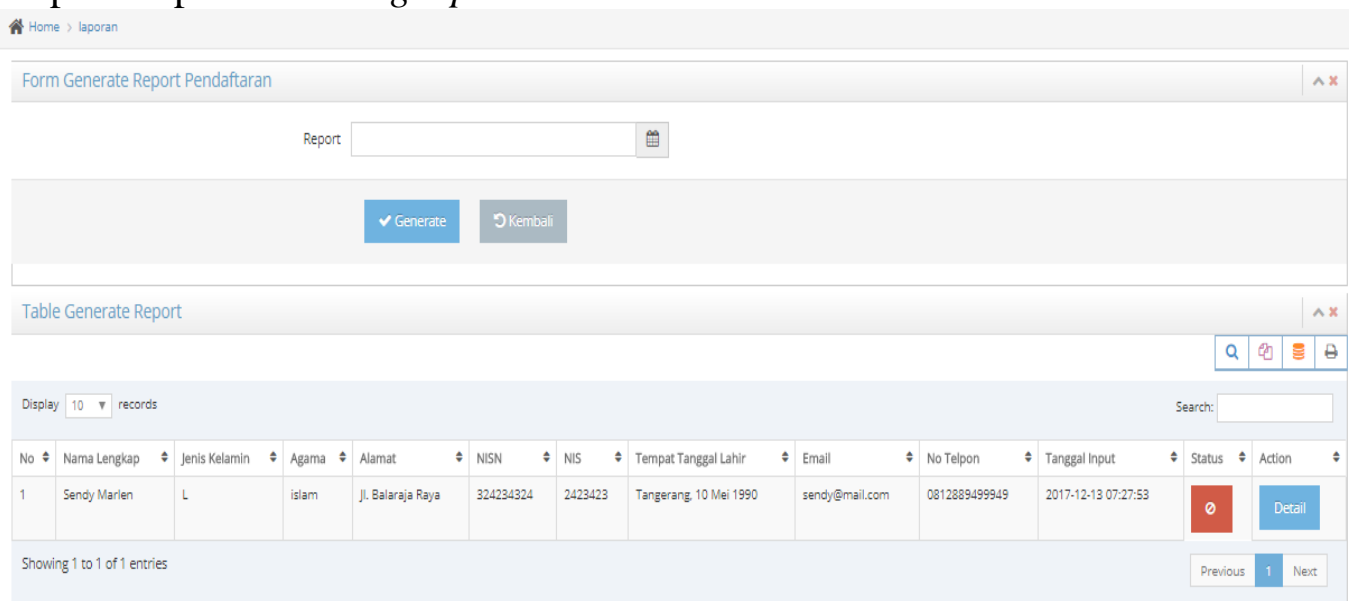

Gambar 17. Tampilan Aplikasi Setting Option 


\section{KESIMPULAN}

Berdasarkan analisa yang telah diuraikan pada bab sebelumnya, penulis menarik kesimpulan sebagai berikut :

1. Sebelum menggunakan sistem pendaftaran, proses pendaftaran siswa baru yang ada pada Sekolah Menengah Atas PGRI Balaraja masih menggunakan cara konvensional dimana calon siswa harus datang dan mengisi form pendaftaran siswa baru dan menyerahkan form tersebut setelah melakukan pengisian data. Namun saat ini sudah menggunakan sistem yang memudahkan calon siswa melakukan pendaftaran secara online tanpa harus datang terlebih dahulu ke sekolah.

2. Sistem pendaftaran sebelumnya tidak terkontrol dengan baik, dari mulai pengisian data dan di input kembali ke komputer hingga pembuatan laporan masih terkendala penggunaan waktu yang lama dan kurang efisien. Saat ini setelah menggunakan sistem pendaftaran siswa baru, semua terkontrol dengan baik dan dapat membuat laporan secara otomatis hanya beberapa kali klik saja.

3. Perancangan yang dilakukan pada Sekolah Menengah Atas PGRI Balaraja dengan cara melakuka analisa kebutuhan, kemudian melakukan analisa dengan metode SWOT dan hingga akhirnya menggunakan metode UML untuk perancangan sistem yang telah di tentukan sesuai dengan kebutuhan.

4. Perancangan yang tepat yang telah di lakukan dengan cara mencari beberapa kelemahan yang ada pada proses pendaftaran siswa baru dan melakukan rancangan untuk menutupi kelemahan tersebut dengan system usulan.

5. Beberapa permasalahan seperti sering terjadi kesamaan data yang sudah di input kemudian di input ulang, proses pendaftaran yang harus datang ke sekolah, proses seleksi penerimaan siswa baru hingga pembuatan laporan saat ini sudah menjadi lebih mudah dan efisiensi waktu serta biaya menjadi lebih terkontrol hingga pemberian informasi pendaftaran menjadi lebih cepat.

\section{DAFTAR PUSTAKA}

[1] Gozali, Lukman, Erwin Gunadhi, Rina Kurniawan. 2012. "Perancangan Sistem Informasi Penjualan Buku Pada PD. Restu Percetakan“. ISSN: 2302-7339 Vol. 09, No. 25:2302-7339

[2] Sukoco, Agus. "Pengembangan Sistem Manajemen Penjualan Dan Stok Gudang Berbasis Web Pada Apotek Dr. Ismangil Kabupaten Blitar". Jurnal Ekonomi dari ISSN: 1412-0879 Vol. 12, No. 1.

[3] Sitorus, Moris Candra. "Sistem Informasi Penjualan Buku Berbasis Web Menggunakan Model View Controller (MVC)”. ISSN: 2301-9425 Vol. 7, No. 2. September 2014

[4] Pujianto. 2012. "Analisis Dan Perancangan Sistem Informasi Penjualan Buku Dengan Konsinyasi Berbasis Client/Server". Vol. 12, No. 2.

[5] Suhartono, Didit, Jaman. "Analisis Dan Perancangan Sistem Informasi Penjualan Buku Dengan Konsinyasi Berbasis Client/Server". Jurnal Probisnis Vol. 7, No. 1. Februari 2014

[6] Andonie, Razvan, J. Edward Russo, Rishi Dean. 2007. “CrossingtheRubicon: AGenericIntelligentAdvisor". Vol. 2, No. 1.

[7] Hui-Ming Kuo, Cheng-Wu Chen. 2011. "Application Of Quality Function Deployment To Improve The Quality Of Internet Shooping Website Interface Design”. Vol. 7, No. 1. 
ISSN: 2461-1409

Online ISSN: 2655-5298

[8] Gangshwer. 2013. "E-Commerce or Internet Marketing: A Business Review from Indian Context”. Vol.6, No.6. Hanafizadeh, Payam, Jeffrey Hsu. 2005. "International Journal Of EBusiness Research". ISSN: 1548-1131.

[9] Gunasekaran, Angappa. 2016. “International Journal of Business Information Systems". ISSN: 17446-0980

[10] Handita, Ditya Banu, Umar, Umi Fadlillah. 2012. "Sistem Informasi Penjualan Berbasis Web Pada Usantex“. Vol. 12, No. 01.

[11] Sukarta, Syntia, Novel Kurniawati Santoso. 2016. "Sistem Informasi Penjualan Batik Berbasis Website Pada Toko Kencana Ayu”. Vol. 1, No. 7. 